\title{
STRATEGINIŲ POKYČIŲ KRYPČIŲ IDENTIFIKAVIMO ORGANIZACIJOSE KONCEPTO PRISTATYMAS
}

\author{
Dalė Miknevičiūtė, Asta Valackienė \\ Kauno technologijos universitetas
}

\begin{abstract}
Anotacija
Organizacinių pokyčių teorinio tyrimų lauko, pasižyminčio fragmentiškumu ir tarpdiscipliniškumu, aprèptis neišvengiamai plečiasi. Tokiam matymui reikia gilesnès, kompleksinès organizacijos veiklos analizès, identifikuoti strategines pokyčių organizacijoje kryptis ir tinkamai pasirengti strateginių pokyčių valdymui. Klasikinėje vadyboje akcentuojami tik pokyčių proceso valdymo klausimai, tačiau šių laikų organizacijų vadovai privalo išgryninti strategines pokyčių kryptis ir pagal jas konstruoti pokyčių organizacijoje valdymo strategiją. Šiame straipsnyje pristatomi strateginių pokyčių krypčių identifikavimo organizacijose teoriniai aspektai, remiantis kitų mokslininkų darbais ir pačių straipsnio autorių teorinèmis įžvalgomis.

PAGRINDINIAI ŽODŽIAI: strateginės pokyčių kryptys, organizaciniai pokyčiai, pokyčių vadyba.
\end{abstract}

Pažymime, kad tyrimai atliekami ir finansuojami pagal Lietuvos mokslo tarybos remiama projekta Nr. 09.3.3-LMT-K-712-03-0073, pateikta igyvendinant 2014-2020 metu Europos Sajungos fondu investiciju veiksmu programos 09.3.3-LMT-K-712 priemone ,,Mokslininku, kitu tyrëju, studentu mokslinès kompetencijos ugdymas per praktinę moksline veikla".

\begin{abstract}
The scope of theoretical research on organizational change, which is characterized by fragmentation and interdisciplinary, is inevitably expanding. Such vision requires a deeper, complex analysis of the organization's activities, identification of directions of strategic changes in the organization and the management of the proper preparation for strategic changes. The classical management focuses only on the issues of the management of the change processes, but the leaders of the present-day organizations must refine the strategic directions of change and follow them, and construct a change management strategy in the organization. This article presents theoretical aspects of the identification of directions of strategic changes in organizations based on the ideas of other researchers and theoretical insights created by the authors themselves.

KEY WORDS: Strategic Change Directions, Organizational Change, Change Management.

We note that research is carried out and financed by the project No. 09.3.3-LMT-K-712-03-0073 supported by the Lithuanian Science Council. Research is submitted in the framework of the Facility for the Investment Facility of the European Union funds for the period 2014-2020, measure 09.3.3-LMT-K-712 "Development of scientific excellence of researchers, other researchers, and students through practical scientific activities".
\end{abstract}

\section{İžanga}

Organizaciniai pokyčiai, kaip socialinis fenomenas, mokslinèje literatūroje (Van Leeuwen ir kt., 2003; Hannan ir kt., 2004; Oreg ir kt., 2011; Schwarz ir kt., 
2008) analizuojami iš skirtingų perspektyvų, papildančių viena kitą ar net viena kitai prieštaraujančių. Nustatyta, kad daugiau dėmesio skiriama pokyčių ir jų valdymo sampratai atskleisti bei pokyčių valdymo modeliams pristatyti. Tačiau reikia pastebèti, kad šioje analizeje pasigendama kompleksinio ir visa apimančio požiūrio. Pasak G. Jacobs ir kt. (2013), organizacinių pokyčių teorinis tyrimų laukas pasižymi fragmentiškumu ir tarpdiscipliniškumu, jis suskaidytas ị tris lygmenis: mikro- - organizacinių pokyčių nulemtus psichologinius žmogiškųjų išteklių aspektus; mezo- - organizacinio lygmens kontekstą; ir makro- - organizacijos aplinką ir sąveiką su kitomis organizacijomis, be to, apima socialinès psichologijos, sociologijos bei ekonomikos mokslus. Taigi organizaciniu pokyčių aprèptis neišvengiamai plečiasi: įtraukianti diskusija perkeliama ir ị vadybos mokslo lauką; tiek analizuojant esminius organizacijos elgsenos pokyčius, tiek apibrèžiant organizacijos strategines perspektyvas (Jacobs ir kt., 2013). Tokiam matymui būtina išsamesne, kompleksinè organizacijos veiklos analizè, svarbu identifikuoti strategines pokyčių organizacijoje kryptis ir pasirengti valdyti strateginius pokyčius.

A. Valackienè (2015), parengusi mokslo studiją, kurioje aptaria pokyčių valdymo, kaip verslo tęstinumo užtikrinimo, strategijos kūrimo aspektus, pokyčių valdymo analizès lauke skiria dvi mąstymo paradigmas. Autore (p. 7) pažymi, kad pirmosios krypties šalininkai aprašo ,pokyčius, kurie atliekami siekiant tobulinti ar net iš esmès keisti vienus ar kitus organizacijos elgsenos elementus; tokius pokyčius lemia išorès aplinkoje arba jos viduje vykstančių kaitos procesų pokyčiai“ (Quinn, 1980; Magnusen, 1981; Carnall, 1990; Zakarevičius, 2003; McNamara, 2008 ir kt.; cit. Valackienè, 2015, p. 7); pokyčiai gyvybiškai svarbūs, tai natūralus ,atsakas“ i vidaus ir aplinkos sąlygas (Leifer, 1989; Luecke, 2003; Todnem, 2005; Burtonshow-Gunn, 2008 ir kt.); pokyčiai yra nuolatinè įmonès gyvavimo ypatybé - natūrali būsena, apimanti tiek operatyvinị, tiek strateginị lygmenis (Todnem, 2005; Burnes, 2004; Recklies, 2001); studijoje A. Valackienè $(2015$, p. 7), remdamasi minètais autoriais; pastebi, kad ,pokyčiai negali būti atskirti nuo įmonès strategijos arba, atvirkščiai, įmonès strategija kuriama ịvertinus pokyčius“; visoms organizacijoms skirta vienoda lemtis: arba ,išnykti patyrus nesėkmę, būti sužlugdytoms konkurencijos, arba pripažinti, kad pokyčiai yra natūrali verslo dalis, skatinanti tobulèti siekiant atitikti vartotojų reikalavimus ar patenkinti jų poreikius“ (Burtonshow-Gunn, 2008). Pasak studijos autorès (Valackienė, 2015), antrosios krypties šalininkai (Kurst, 1995; Johnson, 1987; Morgan, 1986; Zakarevičius, 2003; Staniulienè, 2006 ir kt.) pokyčiais vadina ịmonès aplinkos ir vidaus pokyčius, kurie vyksta objektyviai, nepaisant jos veiklos pobūdžio, rezultatų, vadybos ir kitų aspektų, kurių neįmanoma pakeisti, pakreipti 
kita linkme ar kaip nors paveikti. Vienuose mokslininkų darbuose (Bold, 2011) pokyčiai aprašomi kaip organizacijos kultūros vertybès, kituose (Kalyani, Sahoo, 2011) jie analizuojami kaip žmogiškųų išteklių kompetencijos, pabrèžiant tobulejimą ir inovacijų pritaikomumą, dar kituose (Ford, 2008; Maes, Hootegem, 2011) skiriami pokyčių pranašumai ir trūkumai. S. A. Burtonshow-Gunnas (2008) i pokyčio sampratą įtraukia vartotojo reikalavimų atitikimo ir jo poreikių tenkinimo svarbos ịtaką, jo teigimu, todèl pokyčiai turi būti priimami kaip natūrali verslo dalis.

Reikia pažymėti, kad klasikinèje vadyboje akcentuojami tik pokyčiu proceso suvaldymo klausimai, tačiau šių laikų organizacijų vadovai privalo išgryninti strategines pokyčių kryptis ir ị jas atsižvelgdami konstruoti pokyčių valdymo organizacijoje strategiją. Galima teigti, kad pasigendama esminès nuostatos, konceptualizuojant strateginių pokyčių krypčių identifikavimo lauką pačioje organizacijoje.

Darbo objektas - strateginės pokyčių kryptys organizacijose.

Darbo tikslas - pristatyti strateginių pokyčių krypčių identifikavimo organizacijose konceptą.

Darbo uždaviniai:

- Atskleisti strateginių pokyčių krypčių sampratas.

- Paaiškinti strateginių pokyčių organizacijose krypčių identifikavimo lauką.

\section{Strateginių pokyčių krypčių samprata}

Mokslinèje literatūroje (Kryger, 2017; Fenton ir kt., 2011; G. Hamel, 2012) strategijos formulavimas dažniausia susideda iš misijos formulavimo, siekiant organizacijos vizijos ir tikslų, bei veiksmų, kaip pasiekti išsikeltus tikslus, numatymo. Taigi strateginiu pokyčiu krypčiu samprata visų pirma susijusi su organizacijos planavimo funkcija, tiksliau, su viena svarbiausių planavimo proceso dalių - misijos ir vizijos formulavimu. Užsienio autorių (Kopaneva ir kt., 2015; Babnik ir kt., 2014) teigimu, misija - tai esama organizacijos padètis, tikslas ar organizacijos egzistavimo priežastis, vizija - trokštama padètis, idealios ateities siekis. Remiantis I. Kopaneva ir kt. (2015), misijos ir vizijos teiginiai atitinka tolesnius organizacinius sprendimus ir elgseną, motyvuoja organizacijos narius siekti bendro tikslo. Panašiai aiškina S. Al-Haddad ir kt. (2015): tinkamas planavimas padeda suvokti skirtumą tarp to, kur organizacija yra dabar (misija), ir to, kur ji nori būti (vizija). Tai reiškia, kad vadovai, jau keldami ir formuluodami tikslus, priima tam tikrus organizacinių pokyčių igyvendinimo sprendimus ir žengdami ši žingsnị turi būti numatę tam tikras strategines pokyčių kryptis. 
Analizuojant strateginių pokyčių krypčių sampratą pagal kiekvieną sąvoką atskirai, strategija - tai ilgalaikių tikslų ir uždavinių nustatymas, veiklos nukreipimas bei išteklių paskirstymas (Chandler, 1962); pokyčiai - planuotai ar neplanuotai (Nelson, 2003) laipsniškai vykstantys procesai, turintys įtakos visai organizacijai (Burke, 2017); kryptis - veiksmo, reiškinio linkmè, raidos kelias (Lietuvių kalbos žodynas, 2008), pastarosios sampratos pagrindinè mintis - tai organizacijoje vykstantys esminiai ilgalaikiai pertvarkymai, nukreipti konkrečiomis kryptimis.

Strateginiai pokyčiai - tai svarbiausia organizacijos pokyčių sritis, susijusi su naujos strategijos igyvendinimu (Išoraitė, 2015). M. Hintzberg (1994) teigia, kad tikrieji strateginiai pokyčiai skatina ieškoti naujų organizacijos veiklos krypčių (struktūrinių, procedūrinių, produkcijos ar kt.), ne tik jau vykdomų procedūrų pertvarkymo, todẻl siekiant nustatyti strateginių pokyčių kryptis būtinas vadovų gebejjimas žvelgti ị organizaciją plačiau ir nestandartiškai mąstyti. Taigi strateginių pokyčių krypčių sampratą galima suvokti ne tik kaip tam tikrą organizacijos sriti, kurioje bus vykdomos permainos, bet ir kaip visiškai naujas organizacijos veiklos perspektyvas.

\section{Strateginių pokyčių organizacijose krypčių nustatymas}

S. Lehmanno (2017) teigimu, dauguma pokyčių vadybos teorijų rekomenduoja linijines pokyčių valdymo strategijas (pvz.: J. P. Kotterio (2007) 8 žingsnių teorija, tvirtinanti, kad pokyčių sèkmė pasiekiama igyvendinant 8 etapus; K. Lewino (1948) atšildymo, pakeitimo ir užšaldymo procesų teorija), kurias sudaro skirtingas etapų skaičius, nuosekliai vykdant procesą organizaciniai pokyčiai būtų ịgyvendinti efektyviausiai. Tačiau tam, kad šios teorijos iš tiesų būtų veiksmingos ir naudingos visai organizacijai, būtina nustatyti strategines pokyčių kryptis.

Strateginių pokyčių krypčių nustatymo pagrindas - organizacijos išorinės ir vidinès aplinkos analizè, kuri, pasak A. Baleženčio (2007), leidžia organizacijoms išgyventi ir nuolat atsinaujinti. Tolimosios išorinès (makro-) aplinkos analizei atlikti dažniausia taikoma PEST analizè. PEST apima keturis pagrindinius elementus: politinę, ekonominę, socialinę ir technologinę aplinkas, jas analizuoja strateginiu lygmeniu (Wang ir kt., 2016). Išnagrinejjus aplinkas galima numatyti, kurios iš jų yra palankios, o kurios kelia grèsmes. Plačiai taikomas artimosios išorinès (mikro-) aplinkos ịrankis - M. Porterio penkiu jejgu modelis, kuris apima organizacijos suinteresuotąsias šalis. M. E. Dobbsas (2014) aiškina, kad šis modelis leidžia ịvertinti kiekvienos iš jègų (tiekèjų, vartotojų, esamų ir naujų konkurentų, prekès pakaitalų) ịtaką organizacijai, esamas galimybes ir iššūkius. Nagrinejjant vidinę 
aplinką, pasitelkiama $S S G G$ (SWOT) analizé, išryškinanti organizacijos stipriąsias puses, tobulintinus aspektus, išorinejje aplinkoje atsiveriančias perspektyvas ir kylančias grèsmes (Yuan, 2013). Atlikus išsamias organizacijos aplinkų analizes ir įvertinus gautus rezultatus, galima įžvelgti aplinkoje atsiradusias naujas raidos tendencijas bei numatyti strategines pokyčių kryptis.

Nustatant strateginių pokyčiu kryptis didelès įtakos turi bendravimas su organizacijos darbuotojais. Pasak A. Coghlano ir kt. (2016), organizacijos strategijos supratimas ir jos formavimas nèra vien tik valdančiosios grupès rūpestis, tai turi paveikti ir pavaldinius. Siekiant užtikrinti veiksmingą vadovų ir pavaldinių komunikaciją, A. Krygeris (2017) rekomenduoja pasakojimo technika. Remiantis A. Krygeriu (2017), galima teigti, kad pokalbio metu darbuotojai pasipasakoja, kaip jiems sekasi darbe, apibūdina savo dieną, todèl vadovams būtina įsiklausyti ir atpažinti jų pasakojimuose užkoduotas esmines organizacijos problemas. Tik išsiaiškinus konkrečias problemas, galima numatyti jų atsiradimo priežastis ir sprendimo būdus, ta linkme ir reikia kurti strategiją. A. Krygeris (2017) įžvelgia dar vieną pasakojimo technikos privalumą, susijusi su strategijos iškomunikavimu. Autorius teigia, kad organizacijų vadovai susiduria su iššūkiu, kaip paaiškinti strategiją darbuotojams, kurie neprisidejo prie jos kūrimo, ir taip padèti jiems tinkamai ją suvokti. Pasitelkę pasakojimo techniką, kaip strateginę praktiką ir vadybos įrankį, vadovai gali išspręsti kilusias dviprasmybes, neapibrěžtumą ir painiavą (Kryger, 2017). Kartu tai didintų darbuotojų įsitraukimą ị pokyčių ịgyvendinimo procesą.

Dar vieną iš strateginių pokyčių krypčių identifikavimo teorijų išsamiai pateikia J. Kotteris ir kt. (2008). Remiantis minètais autoriais, galima teigti, kad strateginių pokyčių krypčių nustatymas prasideda apibrèžiant jau vykdomų organizacinių pokyčių situaciją. Tai reiškia, kad vadovai, nustatydami pokyčių ịgyvendinimo trukmę, darbuotojų įtraukimą, planuodami reikiamus išteklius ir kitas papildomas pastangas, tiesiogiai arba netiesiogiai atlieka strateginius pasirinkimus. Šių pasirinkimų nuoseklumas ir pritaikomumas nuolat kintančioje aplinkoje leidžia užtikrinti pokyčių sėkmę, o tie organizaciniai pokyčiai, kurie nesuplanuoti iš anksto ir nepagrịsti aiškia strategija, dažnai žlunga dèl problemų, kurios nebuvo numatytos ir joms nespèta pasiruošti (Kotter ir kt., 2008).

Nustatant strategines pokyčių kryptis, vertinga apsibrèžti pokyčiu suvaldymo būdus ir priemones. J. Kotteris ir kt. (2008) analizuoja strategines organizacinių pokyčių valdymo galimybes, remdamasis L. E. Greinerio (1967), B. Barneso ir kt. (1970) strateginiu kontinuumu (žr. 1 pav.) (kontinuumas - aprěžta, uždara aibė, segmentas, intervalas, žr. Lietuvių kalbos žodynas, 2008). 


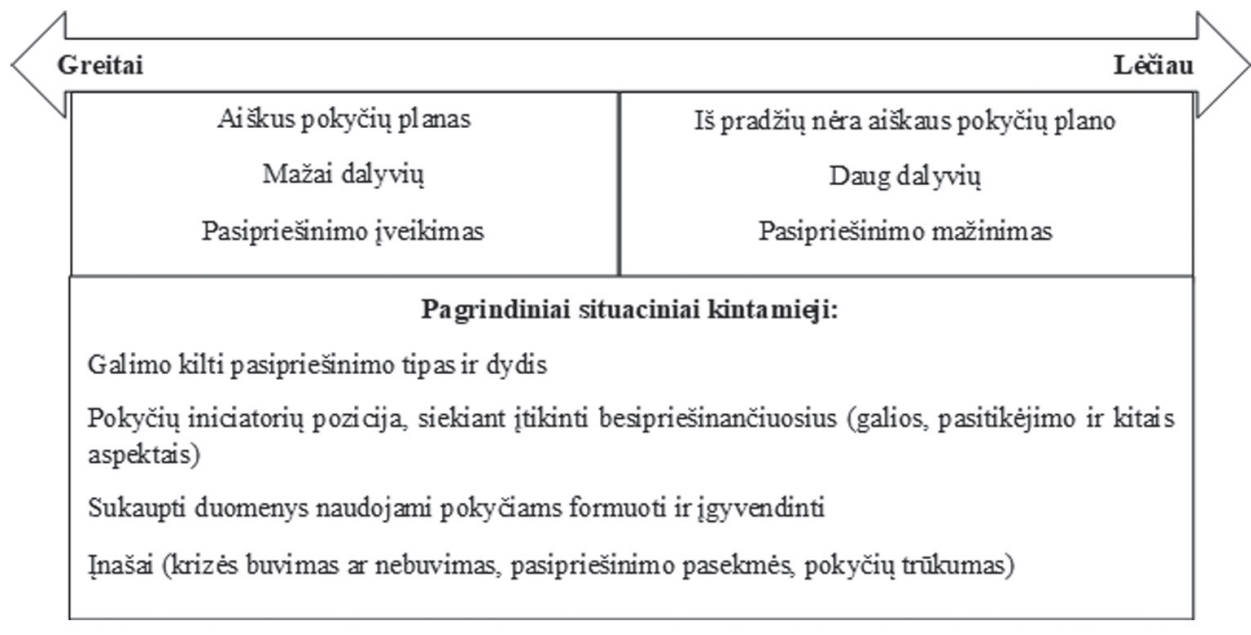

1 pav. Strateginis kontinuumas

(adaptuota remiantis Kotter ir kt., 2008; L. E. Greiner, 1967; Barnes ir kt., 1970)

Strateginis kontinuumas apima dvi kryptis: greitają ir letesnę. Kaip teigia J. Kotteris ir kt. (2008), greitojoje kontinuumo pusejje pokyčių strategijos sparčiai ịgyvendinamos, čia būtinas aiškus pokyčių veiksmų planas, kuriam sudaryti ir ịgyvendinti nereikia gausių žmogiškujų išteklių, dažniausia apsiribojama aukštesniais valdymo lygmenimis. Šio tipo strategija labiau remiasi griežtesnèmis žmogiškujų išteklių valdymo priemonėmis ir yra nukreipta ị bet kokio pasipriešinimo pokyčiams eliminavimą, o tai užtikrina pokyčiams ịgyvendinti numatytų užduočių atlikimą. Kitos kontinuumo pusès strategijos ịgyvendinimo procesai kur kas lètesni, nebūtinas labai aiškus išankstinis planas, įtraukiama daugiau dalyvių (daugiau nei pokyčių iniciatorių). Pokyčiai vyksta laipsniškai, motyvuojant darbuotojus, skiriant laiko bendravimui su jais, kartu skatinant ịsitraukti ị pokyčių procesus. Tokio tipo strategija nukreipta ị pasipriešinimo mažinimą. J. Kotterio ir kt. (2008) teigimu, kuo pasirinkta pokyčių valdymo strategija artimesnè kairiajai (greitajai) pusei, tuo labiau ji linkusi i prievartą ir mažiau taikomi kiti metodai, tokie kaip dalyvavimas ir bendravimas.

Apibendrinant mokslinès literatūros (Baležentis, 2007; Wang ir kt., 2016; M. E. Dobbs, 2014; Yuan, 2013; Coghan ir kt., 2016; Kryger, 2017; Kotter ir kt., 2008; Greiner, 1967; Barnes ir kt., 1970) analize atskleistus strateginiu pokyčiu krypčiu identifikavimo veiksnius: organizacijos aplinku analize, pokalbi su darbuotojais, pokyčiu situacijos aprašyma ir strateginị kontinuuma, sudarytas strateginių pokyčių krypčių identifikavimo lauko raiškos modelis (žr. 2 pav.). Jame pateiktos pagrindinès strateginių pokyčių krypčių nustatymo proceso dedamosios ir jų igyvendinimo alternatyvos. 


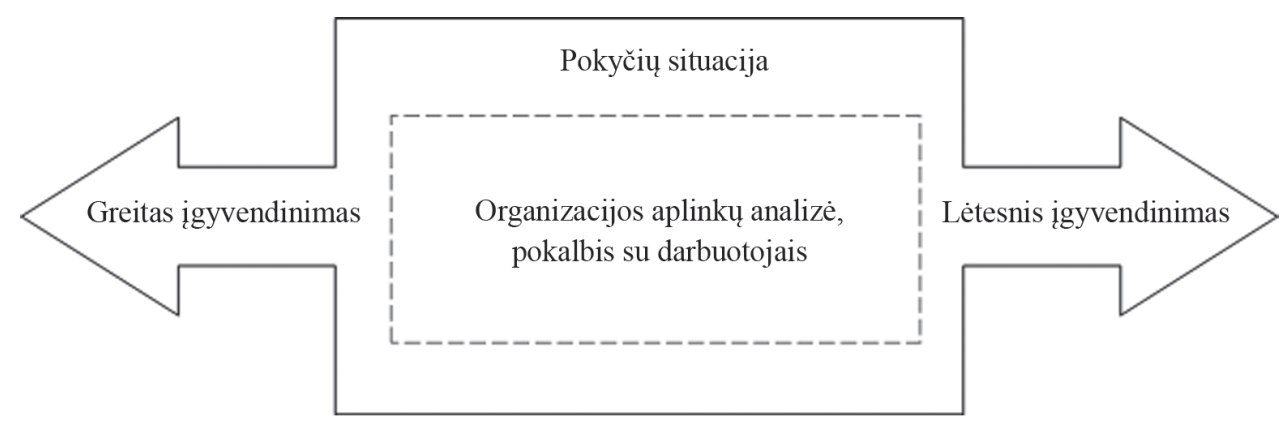

2 pav. Strateginių pokyčių krypčių identifikavimo lauko raiškos modelis (sudaryta darbo autorių)

\section{Išvados}

1. Atlikta mokslinès literatūros analizè padèjo atskleisti organizacinių pokyčių, kaip socialinio fenomeno, raiškos ir strateginių pokyčių krypčių organizacijoje dermés poreikị, lemiantị tolesnius organizacinius sprendimus ir elgseną, be to, motyvuojantị organizacijos narius siekti iškeltų strateginių tikslų. Tokị dermès poreikị diktuoja organizacijos narių suvokimas, kad tinkamas planavimas padeda atskleisti skirtumą tarp to, kur organizacija yra dabar (misija), ir kur ji nori būti (vizija). Taigi vadovai, jau planuodami organizacijos veiklą ir formuluodami tikslus, priima tam tikrus organizacinių pokyčių igyvendinimo sprendimų modelius, vadinasi, jau žengdami ši žingsnį turi būti numatę strategines pokyčių kryptis. Mokslinès literatūros analizè atskleidè, kad strateginių pokyčių krypčių samprata yra plati, numato sisteminio ir holistinio vadovų bei darbuotojų požiūrio ị organizacijoje vykstančius procesus įvertinimą. Pabrèžtina, kad strateginių pokyčių krypčių sampratoje išryškejjo keletas dedamujų: visų pirma strateginės pokyčių kryptys atsiskleidžia kaip bendras organizacijos planavimo funkcijos, misijos ir vizijos apibrèžtumo kompleksas; antra - kaip ilgalaikiai organizacijos pertvarkymai konkrečiose srityse ir veiklose; trečia - kaip naujų pokyčių numatymas.

2. Mokslinès diskusijos, aptariant strateginių pokyčiu organizacijose krypčių identifikavimo lauką, skatina matyti plačiau, įtraukiant tarpdisciplininį teorinį kontekstą. Nustatyta, kad strateginių pokyčių krypčiu identifikavimo laukas organizacijose aprépia organizacijos išorinès (mikro- ir makro-) bei vidinès aplinkų analizę. Atskleista, kad numatant strategines pokyčių kryptis didelès įtakos turi bendravimas su organizacijos darbuotojais, todèl kita 
labai svarbi dedamoji šiame lauke yra pokalbiai su jais. Būtina parengti organizacinių pokyčių situacijos aprašymą ir pagrịsti strateginio kontinuumo, kuris apima greito arba lètesnio pokyčiu igyvendinimo organizacijoje alternatyvas. Remiantis teorinėmis įžvalgomis, parengtas strateginių pokyčių krypčių identifikavimo lauko raiškos modelis, igalinantis atskleisti pagrindinès strateginių pokyčių krypčių nustatymo proceso dedamąsias ir jų įgyvendinimo alternatyvas.

\section{Literatūra}

Al-Haddad, S., Kotnour, T. (2015). Integrating the organizational change literature: a model for successful change. Journal of Organizational Change Management, Vol. 28(2), p. 234-262.

Babnik, K., Breznik, K., Dermol, V., Trunk, Š. N. (2014). The mission statement: Organizational culture perspective. Industrial Management \& Data Systems, Vol. 114, p. 612-627.

Baležentis, A. (2007). Organizacijos inovacinio lauko veiksnio analizè. Viešoji politika ir administravimas, Nr. 22, p. 41-46.

Bold, E. (2011). Instruments and techniques used in the design and implementation of change management. Journal of advanced research in management, Vol. 1, p. 4-17.

Burke, W. W. (2017). Organization Change - Theory and Practice. 5th ed. California: Sage. Prieiga internete: https://goo.gl/gLSwCp [žiūrèta 2017-10-13].

Burnes, B. (2004). Managing changes: a strategic approach to organizational dynamics. Harlow.

Burtonshow-Gunn, S. A. (2009). Svarbiausios vadybos priemonés: metodai, modeliai, pastabos vadovams ir konsultantams. Vilnius.

Carnall, C. A. (1990). Managing Change in Organizations. Prentice Hall.

Chandler, A. D. (1962). Strategy and Structure. Cambridge: M.I.T. Press.

Coghlan, D., Rashford, N. S., de Figueiredo, J. N. (2016). Organizational Change and Strategy - An Interlever Approach. 2nd ed. London and New York: Routledge, Taylor \& Francis Group. Prieiga internete: https:// goo.gl/MgSZbn [žiūrèta 2017-11-10].

Dobbs, M. E. (2014). Guidelines for applying Porter's five forces framework: a set of industry analysis templates. Competiveness Review, Vol. 24(1), p. 32-45.

Fenton, C., Langley, A. (2011). Strategy as practice and the narrative turn. Organization Studies, Vol. 32(9), p. 1171-1196.

Ford, R. (2008). Complex adaptive systems and improvisation theory: Towards framing a model to enable continous change. Journal of change management, Vol. 8 (3/4), p. 173-198.

Hamel, G. (2012). What Matters Now: How to Win in a World of Relentless Change, Ferociuos Competition, and Unstoppable Innovation. San Francisco, CA.: Jossey-Bass.

Hannan, M. T., Polos, L., Carroll, G. R. (2004). The evolution of inertia. Industrial an Corporate Change, Vol. 13(1), p. 213-242.

Išoraitè, M. (2012). Teoriniai strateginių pokyčių krypčių aspektai. Business systems and economics, Vol. 2(2), p. $130-145$.

Yuan, H. (2013). A SWOT analysis of successful construction waste management. Journal of Cleaner Production, Vol. 39, p. 1-8.

Jacobs, G., van Witteloostuijn, A., Christe-Zeyse, J. (2013). A theoretical framwork of organizational change. Journal of Organizational Change Management, Vol. 26(5), p. 772-792.

Johnson, G. (1987). Strategic change and the management process. Oxford: Blackwell.

Kalyani, M., Sahoo, M. P. (2011). Human resource strategy: a tool of managing change for organizational excellence. International journal of business and management, Vol. 6(8), p. 280-286.

Kopaneva, I., Sias, P. M. (2015). Lost in Translation: Employee and Organizational Constructions of Mission and Vision. Management Comunication Quarterly, Vol. 29(3), p. 358-384.

Kotter, J. P., Schlesinger, L. A. (2008). Choosing Strategies for Change. Harward Business Review, July-August, p. 130-138. 
Kryger, A. (2017). Strategy development through interview technique from narrative therapy. Journal of Organizational Change Management, Vol. 30(1), p. 4-14.

Lehmann, S. (2017). Bridging Strategies and Action: Towards a Method for Change Management in Danish Emergency Management Organizations. Journal of Change anagement, Vol. 17(2), p. 138-154.

Lietuvių kalbos žodynas. (2008). T. 1-20. (1941-2002). Elektroninis variantas. Vilnius: Lietuvių kalbos institutas. Prieiga internete: http://www.lkz.lt/ [žiūrèta 2017-10-11].

Maes, G., Hootegem, G. (2011). Toward a dynamic description of the attributes of organizational change. Research in Organizational Change and Development, Vol. 19, p. 121-231.

Magnusen, K. (1981). Organization design, development and behavior. Chicago: Rand McNally.

McNamara, C. (2006). Field guide to consulting and organizational development: A collaborative and systems approach to performance, change and learning. Authenticity Consulting.

Mintzberg, H. (1994). The Fall and Rise of Strategic Planning. Harward Business Review. January - February, p. $107-114$.

Morgan, D. E., Zeffane, R. (1987). Employee involvement, organisational change and trust in management. The International Journal of Human Resource Management, Vol. 14 (1), p. 55-75.

Nelson, L. (2003). A case study in organisational change: implications for theory. The Learning Organization, Vol. 10(1), p. 18-30.

Oreg, S., Vakola, S., Armenakis, A. (2011). Change recipients' reactions to organizational change: a 60-year review of quantitative studies. The Journal of Applied Behavioral Science, Vol. 47(4), p. 461-524.

Quinn J. (1980). Strategies for change: Logical incrementalism. Richard D. Irwin, Homewood Ill.

Recklies, O. (2001). Managing Change - Definition and phases in change processes. Recklies Management Project GmbH, p. 1-3.

Schwarz, G. M., Huber, G. P. (2008). Challenging organizational change research. British Journal of Management, Vol. 19, S1-S6.

Staniulienè, S. (2006). Organizavimas ir ergoprojektavimas. Kaunas: Vytauto Didžiojo universitetas.

Todnem, R. (2005). Organizational change management: A critical review. Journal of change management, Vol. 5 (4), p. 369-380.

Valackienė, A. (2015). Pokyčiu valdymas siekiant užtikrinti verslo tęstinumą. Mokslo studija. Kaunas: Technologija.

Van Leeuwen, E., van Knippenberg, D., Ellemers, N. (2003). Continuing and Changing Group Identities: The Effects of Merging on Social Identification and Ingroup Bias. Society for Personality and Social Psychology, Vol. 29(6), p. 679-690.

Wang, P., Zheng, G. (2016). PEST Analysis on Dark Tourism Development in China. Asian Agricultural Research, Vol. 8(8), p. 31-34.

Zakarevičius, P. (2003). Pokyčiai organizacijose: priežastys, valdymas, pasekmès. Kaunas.

\section{PRESENTATION OF THE CONCEPT OF IDENTIFICATION STRATEGIC CHANGE TRENDS IN ORGANIZATIONS}

\section{Dalè Miknevičiūtè, Asta Valackienė}

Summary

This article presents the main idea seeking to highlight how to identify directions of strategic changes in organizations based on the concepts of other researchers and theoretical insights created by the authors themselves.

The analysis of scientific literature has helped to reveal the need for a harmony of organizational changes as an expression of the social phenomenon and the di- 
rections of strategic changes in the organization, responding to further organizational decisions and behaviour, as well as motivating members of the organization to achieve the set strategic goals. This need for harmony is dictated by the perception of the organization's members that proper planning helps to uncover the distinction between where the organization is now (mission) and where it wants to be (the vision). This explains that managers are already adopting certain models of organizational change implementation decisions when planning the organization's activities and formulating goals, which means that strategic change directions must already be envisaged in this step. The analysis of scientific literature has shown that the concept of strategic change directions is broad and requires a systematic and holistic assessment of the attitude of managers and employees towards the processes taking place in the organization. It should be emphasized that several concepts have emerged in the concept of strategic change directions: first of all, strategic directions of change unfold as a unified organization planning function, mission and vision set; secondly, as long-term organizational transformations in certain, specific areas and activities; the third is the anticipation of the prospects for the completely new developments.

A scientific discussion, discussing the field of identifying areas of strategic change in organizations, requires a broader view, involving an interdisciplinary theoretical context. It has been established that the field of identification of strategic change directions in organizations includes the external (micro and macro) and internal analysis of the organization. Communication with employees of the organization is strongly influenced by the identification of the directions of strategic change, therefore another important component in this field is interviews with employees. It is necessary to prepare for the description of the situation of organizational change and to justify the alternatives to strategic continuity, which includes quick or slow changes in the organization's implementation. Based on theoretical insights, a field-definition model for the identification of strategic change directions has been developed, which enables to reveal the main components of the process of identifying trends of strategic changes, and alternatives to their implementation. 